PROBLEMS

OF EDUCATION

IN THE $21^{\text {st }}$ CENTURY

Volume 51, 2013

104

INVESTIGATING MOTIVATION OF PRIMARY AND SECONDARY SCHOOL TEACHERS IN TERMS OF DEMOGRAFIC VARIABLES ACCORDING TO TEACHER OPINIONS: A CASE OF TURKEY

\author{
Ergün Recepoğlu \\ Kastamonu University, Kastamonu, Turkey \\ E-mail: erecepoglu@kastamonu.edu.tr
}

\begin{abstract}
Motivation is of great importance for social and work life as motivation emerges in every aspect of life. The aim of this research is to analyze job motivation of primary and secondary school teachers. This is a descriptive research in the survey model. The sample of the study is 305 teachers employed in primary and secondary schools in Karabük in Turkey. As a data collection instrument "Job Motivation Scale" developed by Aksoy (2006) was used. The frequency, percentage, arithmetical mean and standard deviation of the answers were calculated. Independent t-Test and One-Way ANOVA were performed to analyze the data. According to research findings, Job motivation of teachers in primary and secondary schools shows a significant difference in terms of age, tenure of office while motivation of teachers do not show a significant difference in terms of teachers'gender, education level and branch.
\end{abstract}

Key words: motivation, primary and secondary school, teacher.

\title{
Introduction
}

Motivation is of great importance for social and work life as motivation emerges in every aspect of life. Motivation is a strong desire to make something. This desire comes from inside of individuals. People take pleasure in what they do if they do it willingly and feel well about themselves. As a result, they work efficiently and effectively.

Motivation is a vital element of organizational behavior as a factor which directs and reveals the human behaviors in an organization (Örücü and Kambur, 2008). Motivation is a term used for defining the success or the failure of any complex task (Brown, 1994). Motivation can be defined as the power that directs the behavior to target or enacts the behavior according to a purpose (Öztürk and Dündar, 2003). Harmer (2001:51) defined motivation as "some kind of internal drive which pushes someone to do things in order to achieve something". Steers and Porter (1991:6) deal with three matters while discussing motivation: (1) what energizes human behavior, (2) what directs or channels such behavior, (3) how this behavior is maintained or sustained. Dörnyei (2001) stated that motivation is thought to be responsible for "why people decide to do something, how long they are willing to sustain the activity and how hard they are going to pursue it".

Ryan and Deci (2000:54) state that "to be motivated means to be moved to do something". Unlike unmotivated people who have lost impetus and inspiration to act, motivated people are energized and activated to the end of a task. "Interest, curiosity, or a desire to achieve" (Williams and Burden, 1997:111) are the key factors that compose motivated people.

Job motivation is regarded as a process that empowers, feeds and directs the behavior 
in an organization (Leonard et al., 1999). Job motivation is described as the psychological processes that direct, energize, and maintain action toward a job, task, role, or project (Campbell

PROBLEMS

OF EDUCATION

IN THE $211^{\text {st }}$ CENTURY

Volume 51,2013

\& Pritchard, 1976; Kanfer, 1990). Job motivation was defined in terms of a set of independent/ dependant variable's relationships that explains direction, aptitude, and persistence of an individual's behavior holding constant effects of aptitude, skill and understanding of the task, and the constraints operating in the environment (Campbell and Pritchard, 1976). Steers and Porter (1991) defined job motivation as that which drives and sustains human behavior in working life. Pinder (1998) described job motivation as a set of internal and external forces that initiates work related behavior and determines its form, direction, intensity and duration.

The importance of job motivation is stated by Grant and Shin (2011) as in the following:

Work motivation is an important phenomenon for both scholars and practitioners to understand. It helps to explain what drove Thomas Edison to invent the first light bulb, Florence Nightingale to improve nursing practices, Nelson Mandela to become the president of South Africa, Benjamin Franklin to create fire and police departments, Maya Angelou to write poetry, and Michelangelo to paint the Sistine Chapel. Knowledge of work motivation also has the potential to shed light on major collective accomplishments such as discovering flight, landing on the moon, curing river blindness, and inventing the telephone and the computer. Underlying all of these accomplishments is a desire to take action.

The sources of motivation that people have in workplace might be different. Intrinsic motivation is an incentive that is shaped by person's interest for a duty or a job he/she is going to do, his/her curiosity or the satisfaction he/she wants to have. Person's relish and desire for the work he/she is going to do is an important component of intrinsic motivation (Joo and Lim, 2009). If a person firstly cares the satisfaction, which he/she has while indicating a certain behavior or he was in a certain activity, we can mention about intrinsic motivation there. In intrinsic motivation, the job itself is a power because the person has fun from the work he/she carries out (Cooman et al., 2007; Lin, 2007; Littlejohn, 2008; Millette and Gagne, 2008; Osterloh et al., 2001). In other words, it is known that a person with intrinsic motivation defines his or her job funny and interesting (Gagne et al., 2010). Extrinsic motivation refers to meeting the needs indirectly by money or such things. Organizations need people to realize their purposes and they use monetary motivators to make them internalize the organizational purposes (Osterloh et al., 2001). Therefore, extrinsic motivation is caused by prize and punishment on contrary to the intrinsic motivation (Goodridge, 2006; Littlejohn, 2008).

Motivation appears to be an effective tool that teachers need mostly recently. Teachers who have a high motivation work efficiently and effectively and it is of great importance for teachers in terms of their job satisfaction and job performance. In addition, a high job motivation of teachers can have a positive impact on the achievements of students.

Johnson (1986) states that there are three theories of motivation and productivity that teacher motivation is based on.

- Expectancy theory: It is probable for a person to struggle for work if there is an expected reward such a bonus or a promotion that is worth working.

- Equity theory: Unfair treatment for their efforts and achievements makes individuals displeased.

- Job enrichment theory. The more varied and challenging their work is, the more productive employees become.

The efficiency and strength of an educational system greatly depends on teachers. It is teacher morale and motivation which have a determining factor in the success of students, schools and country. Teachers are instrumental in transforming an individual into a person of imagination, wisdom, human love and enlightenment, and institutions into lampposts of posterity, and the country into a learning society. Searching and evaluating the factors affecting teach- 


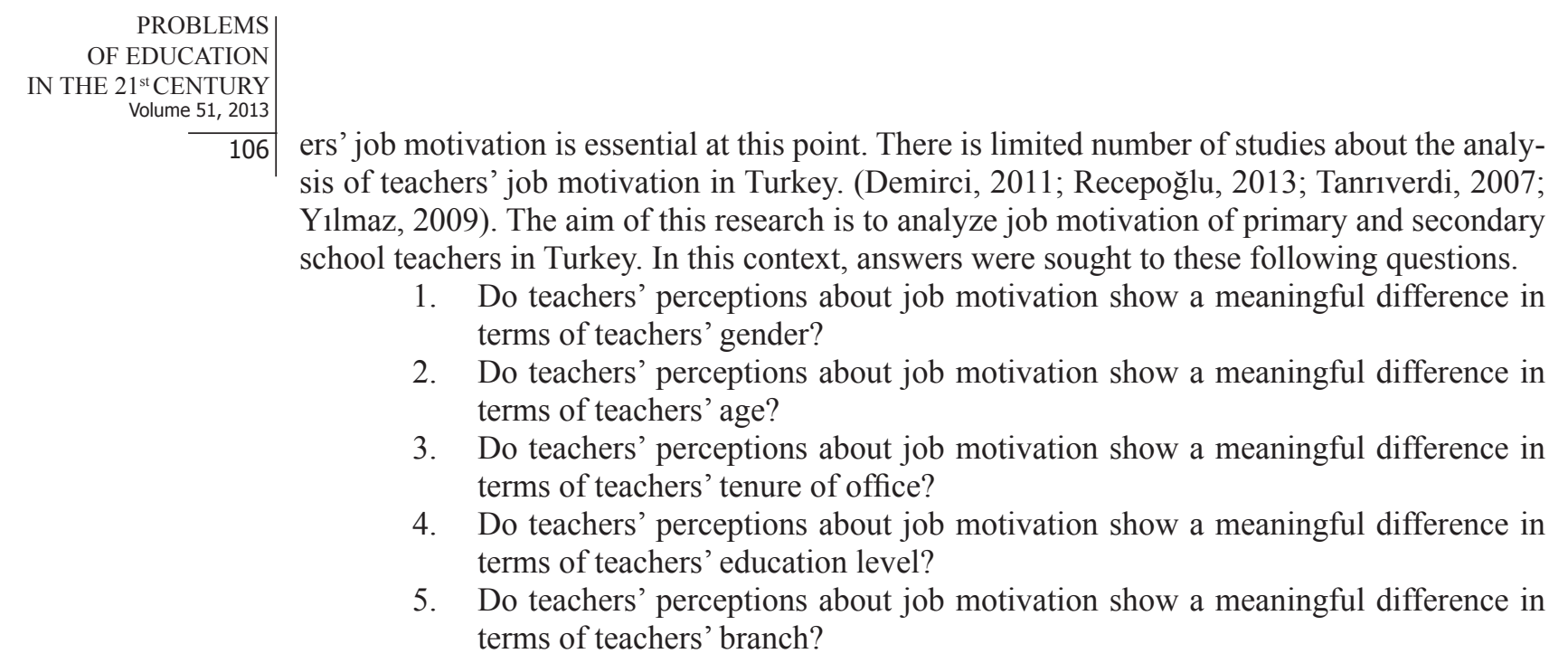

Methodology of Research

General Background of Research

This is a descriptive research in the survey model. According to Karasar (1999) scanning models are research approaches which aim to define a past or present situation..

\section{Sample of Research}

A total of 305 teachers employed in primary and secondary schools in Karabük participated in the study. Random sampling method was used for teacher choosing. Teachers were selected from 10 primary and 10 secondary schools. The sample of research included 142 (46. $6 \%$ ) classroom teachers and $163(53.4 \%)$ branch teachers. Out of these teachers, 131 teachers $(43 \%)$ are male and 174 teachers $(57 \%)$ are female. $88(28.9 \%)$ teachers are between the ages of 22 to $30,112(36.7 \%)$ are between 31 to $40,79(25.9 \%)$ are between 41 to 50 and $26(8.5 \%)$ are above 51 years old. Teachers who have seniority between 1 to 5 years are $66(21.6 \%)$, who have seniority between 6 to 10 years are $51(16.7 \%)$, who have seniority between 11 to 20 years are $120(39.3 \%)$ and who have seniority above 21 years are $68(22,3 \%)$. Among the teachers who participated in the study, 248 of them have bachelor's degree $(81.3 \%), 42(13.7 \%)$ of them have pre-bachelor's degree, 13 (4.1\%) of them have master's degree and only $3(0.9 \%)$ of them have $\mathrm{PhD}$.

\section{Instrument and Procedures}

As a data collection instrument "Job Motivation Scale" developed by Aksoy (2006) was used. A Likert scale of five was used for each item to detect the frequency of indicating the behaviour. The scale items were answered on a rating scale from 1 "I'm not pleased at all" to 5 "I am really pleased". Yilmaz (2009) applied a factor analysis to Aksoy's scale in his thesis study entitled as "The effect of organizational culture on teachers' job motivation in educational organizations". The results of factor analysis conducted by Yllmaz (2009) reveal that Kaiser Meyer-Olkin Sample measure was found 0.781. Considering these results Bartlett's Test of Sphericity value was significant and it was found 470.77 . This result indicates that there is a relationship among the items of the scale. Results of factor analysis indicated that the scale items were distributed across six factors, however it was also seen that one subscale was consisted of two items and one was consisted of one item. Hence items included in these subscales were taken out of the scale and it was re-analyzed. In the second factor analysis it had been seen that one dimension had still included only one item and it had been taken out of the scale and the 
Ergün RECEPOĞLU. Investigating Motivation of Primary and Secondary School Teachers in Terms of Demografic Variables According to Teacher Opinions: A Case of Turkey

factor analysis was conducted again. As a result of the repeated analyses after taking out items off the list it was seen that scale includes four dimensions and 14 items namely; team harmony armony, from 0.54 to 0.78 in the dimension of integration with the job, from 0.59 to 0.81
mension of commitment to job, and from 0.43 to 0.73 in the dimension of personal 
ROBLEMS

OF EDUCATION

IN THE $21^{\text {st }}$ CENTURY Volume 51,2013

108 teachers at 41-50 ages. There is also a meaningful difference between teachers at 22-30 ages and the teachers at 22-30 ages. According to Tukey HSD test, it is determined that motivation of the teachers at 22-30 ages $(\bar{X}=3.82)$ is higher than the teachers at 41-50 ages $(\bar{X}=3.50)$ and the teachers at $31-40$ ages $(\bar{X}=3.57)$. There is also a meaningful difference between teachers at 41-50 ages and the teachers at 51 ages and over. It is determined that motivation of the teachers at 51 ages and over $(\bar{X}=3.87)$ is higher than the teachers at $41-50$ ages $(\bar{X}=3.50$.

ANOVA results according to teachers' tenure of office in their schools are shown in Table 3 in terms of Job Motivation Scale.

Table 3. ANOVA results for motivation of teachers according to teachers' tenure of office.

\begin{tabular}{llcccccc}
\hline \multicolumn{1}{c}{ Tenure of office } & $\mathbf{N}$ & $\overline{\mathrm{X}}$ & $\mathbf{S}$ & $\mathrm{SD}$ & $\mathbf{F}$ & $\mathbf{p}$ & Mean. Difference \\
\hline 1. 1-5 years & 66 & 3.90 & 0.58 & & & & $1-2^{*}$ \\
2. 6-10 years & 51 & 3.48 & 0.62 & 3 & & & $1-3^{*}$ \\
3. 11-15 years & 120 & 3.54 & 0.55 & 301 & 7.34 & 0.00 & \\
4. 16 year and over & 68 & 3.72 & 0.53 & & & & \\
\hline
\end{tabular}

According to the results of the analysis, motivation of teachers in primary and secondary schools show a meaningful difference according to teachers' tenure of office $\left[\mathrm{F}_{(3-301)}=7.34, \mathrm{p}<\right.$ 0.05]. In other words, teachers' tenure of office affects motivation of teachers in primary and secondary schools. Tukey HSD test was done in order to determine the groups which have a meaningful difference between them. There is a meaningful difference between teachers whose tenure of office is 1-5 years and teachers whose tenure of office 6-10 years. There is also a meaningful difference between teachers whose tenure of office is 1-5 years and teachers whose tenure of office 11-15 years. The motivation of teachers who have $1-5$ years of tenure of office $(\bar{X}=3.90)$ is higher than the mean of teachers who have 6-10 years of tenure of office $(\bar{X}=3.48)$ and the mean of teachers who have 11-15 years of tenure of office $\overline{(\mathrm{X}}=3.54)$.

ANOVA results according to teachers' educational level in their schools are shown in Table 4 in terms of Job Motivation Scale.

Table 4. ANOVA results for motivation of teachers according to teachers' educational level.

\begin{tabular}{llllllll}
\hline Educational Level & $\mathrm{N}$ & $\overline{\mathrm{X}}$ & $\mathrm{s}$ & $\mathrm{SD}$ & $\mathrm{F}$ & $\mathrm{p}$ Mean. Difference \\
\hline 1. Associate degree & 42 & 3.76 & 0.45 & 3 & 2.50 & 0.059 & - \\
2. Bachelor's degree & 248 & 3.65 & 0.58 & 301 & & & \\
3. Master's degree & 12 & 3.28 & 0.59 & & & & \\
4. Doctorate degree & 3 & 3.30 & 1.69 & & & & \\
\hline
\end{tabular}

According to the results of the analysis, motivation of teachers in primary and secondary schools doesn't show a meaningful difference according to their educational level $\left[\mathrm{F}_{(3-301)}=\right.$ $2.50, p>0.01]$. In other words, motivation of teachers in primary and secondary schools doesn't change according to teachers' educational level.

T-test was done in order to determine whether motivation of teachers in primary and secondary schools shows a significant difference or not according to teachers' branch. T-test results according to teachers' branch are shown in Table 5 in terms of Job Motivation Scale. 
Table 5. T-test results about motivation of teachers according to branch.

\begin{tabular}{lllllll}
\hline Branch & $\mathbf{N}$ & $\overline{\mathrm{X}}$ & $\mathbf{s}$ & $\mathrm{SD}$ & $\mathbf{t}$ & $\mathrm{p}$ \\
\hline Primary school teachers & 131 & 3.69 & 0.55 & 303 & 1.22 & 0.22 \\
Secondary school teachers & 174 & 3.61 & 0.60 & & & \\
\hline
\end{tabular}

According to the results of the analysis, motivation of teachers in primary and secondary schools do not show a meaningful difference according to gender $\left.\left[\mathrm{t}_{(303}\right)=1.22, \mathrm{p}>0.05\right]$. In other words, primary and secondary school teachers have same perceptions.

\section{Discussion}

Motivation of teachers in primary and secondary schools do not show a meaningful difference according to gender. Male and female teachers have the same perceptions. This finding can be evaluated like that factors that motivate teachers do not change according to gender. The findings are similar with the researches done by Aksoy (2006), Güven (2007), Eroğlu (2007), Everett (1988), Oades (1983), Pennington (1997), Recepoglu (2013), Smith (1999), Tanriverdi (2007), Tiryaki (2008) and Yilmaz (2009).

Motivation of teachers in primary and secondary schools shows a meaningful difference according to their ages. Motivation of teachers in primary and secondary schools changes according to teachers' ages. While the teachers at 41-50 ages stated most negative opinion, both the teachers at 22-30 ages and teachers at 51 ages and over stated most positive opinion about their motivation. This situation can be explained by the enthusiasm of starting a new career in teaching profession. The more they get older, their motivation decrease. However it is remarkable that the teachers at 51 ages and over have the highest motivation. This situation can be explained by the fact that the older teachers who are closer to retirement may have the higher professional satisfaction in their schools. But it mustn't be disregarded that this finding may stem from the fact that young teachers' expectations are higher than the others. The findings are similar with the research done by Recepoglu (2013). The findings aren't similar with the researches done by Aksoy (2006), Güven (2007), Everett (1988), Oades (1983), Pennington (1997), Smith (1999), Tiryaki (2008), Tanrıverdi (2007) and Yilmaz (2009). In these researches, it was determined that motivation of teachers does not show a meaningful difference according to teachers' ages.

Motivation of teachers in primary and secondary schools shows a meaningful difference according to teachers' tenure of office. Teachers' tenure of office affects motivation of teachers in primary and secondary schools. Tukey HSD test was done in order to determine the groups which have a meaningful difference between them. It is remarkable that the new teachers who have 1-5 years of tenure of office have highest motivation. This situation can be explained by the enthusiasm of starting a new career in teaching profession. The findings aren't similar with the researches done by Everett (1988), Güven (2007), Howard (2007), Pennington (1997), Smith (1999), Tanrıverdi (2007) and Yilmaz (2009). In these researches, it was determined that motivation of teachers does not show a meaningful difference according to teachers' tenure of office. The findings are partly similar with the researches done by Öztürk (2002) and Engin (2004). The findings are similar with the research done by Recepoglu (2013).

Motivation of teachers in primary and secondary schools doesn't show a meaningful difference according to their educational level. Motivation of teachers in primary and secondary schools doesn't change according to teachers' educational level. This finding can be evaluated like that factors that motivate teachers do not change according to teachers' educational level. Findings aren't similar with the research done by Recepoğlu (2013). According to the results of that study, motivation of teachers in primary and secondary schools shows a meaningful difference according to their educational level.

Motivation of teachers in primary and secondary schools do not show a meaningful dif- 
PROBLEMS

OF EDUCATION

IN THE $21^{\text {st }}$ CENTURY Volume 51,2013

110 ference according to branch. In other words, primary and secondary school teachers have the same perceptions. This finding can be evaluated like that factors that motivate teachers do not change according to branch.

\section{Conclusions}

As a conclusion, according to the perceptions of the teachers, Job motivation of teachers in primary and secondary schools shows a significant difference in terms of age and tenure of office while motivation of teachers do not show a significant difference in terms of teachers' gender, educational level and branch. This finding shows that age and tenure of office are significant variables that affect job motivation of primary and secondary school teachers. The teachers at 41-50 ages stated most negative opinion, both the teachers at 22-30 ages and teachers at 51 ages and over stated most positive opinion about their motivation. This situation can be explained by the enthusiasm of starting a new career in teaching profession. The more they get older, their motivation decrease. However it is remarkable that the teachers at 51 ages and over have the highest motivation. The older teachers who are closer to retirement may have the higher professional satisfaction in their schools. But it mustn't be disregarded that this finding may stem from the fact that young teachers' expectations are higher than the others. It is also remarkable that the new teachers who have 1-5 years of tenure of office have highest motivation. This situation can be explained by the enthusiasm of starting a new career in teaching profession.

Job motivation of teachers can be analyzed with new and different data collection instruments. The scope of the study may be expanded. Researches may be applied not only also in primary and secondary schools but also in higher education institutions. This research includes only teachers. School principals, assistant principals and academic staff may be included in the study.

\section{References}

Aksoy, H. (2006). Örgüt ikliminin motivasyon üzerine etkisi. Yayımlanmamış Yüksek Lisans Tezi, Marmara Üniversitesi Sosyal Bilimler Enstitüsü, İstanbul.

Brown, H. D. (1994). Principles of Language Learning and Teaching. New Jersey: Prentice Hall Regents.

Campbell, D. J., \& Pritchard, R. (1976). Motivation theory in industrial and organizational psychology. In M.D. Dunnette (Ed.), Handbook of industrial and organizational Psychology (pp. 63-130). Chicago: Rand McNally.

Cooman, R. D., Gieter, S. D., Pepermans, R., Bois, C. D., Caers, R., \& Jegers, M. (2007). Graduate teacher motivation for choosing a job in education. The International Journal for Educational and Vocational Guidance, 7, 123-136.

Demirci, O. (2011). Illköğretim okullarında çalışan sözleşmeli ve kadrolu öğretmenlerin özlük haklarındaki farklılıklar ve iş motivasyonu. Yayımlanmamıș Yüksek Lisans Tezi. Uşak Üniversitesi, Sosyal Bilimler Enstitüsü, Uşak.

Dörnyei, Z. (2001). Motivational Strategies in the Language Classroom. Cambridge: Cambridge University Press.

Engin, E. (2004). Psikiyatri kliniğinde çalışan hemşirelerin öfke düzeyleri ile iş motivasyonları arasındaki ilişkinin incelenmesi. Yayımlanmamış Doktora Tezi, Ege Üniversitesi Sağlık Bilimleri Enstitüsü, İzmir.

Eroğlu, S. (2007). Toplam kalite yönetimi uygulanan orta ögretim kurumlarında ögretmenlerin örgütsel adanmışlık ve motivasyon düzeyleri. Yayımlanmamış Yüksek Lisans Tezi, Yeditepe Üniversitesi Sosyal Bilimler Enstitüsü, İstanbul.

Everett, G. B. (1988). A study of the relationship between principal's leadership style and the level of motivation of the teaching staff. Yayımlanmamıs Doktora Tezi, Tennessee State University Graduate School, Tennessee. 
Ergün RECEPOĞLU. Investigating Motivation of Primary and Secondary School Teachers in Terms of Demografic Variables According to Teacher Opinions: A Case of Turkey

Gagne, M., Forest, J., Gilbert, M. H., Aube, C., Morin, E., \& Malorni, A. (2010). The motivation at work scale: Validation evidence in two languages. Educational and Psychological Measurement, 70 (4), 628-646.

Güven, A. (2007). Kamu yöneticilerinin davranış tarzlarının personelin motivasyonu üzerine etkileri: Tokat il milli eğitim müdürlüğünde çalışan ögretmenler üzerinde bir uygulama. Yayımlanmamış Yüksek Lisans Tezi, Gazi Osman Paşa Üniversitesi Sosyal Bilimler Enstitüsü, Tokat.

Goodridge, D. (2006). Relationships between transformational and transactional leadership with the motivation of subordinates. Unpublished Master Thesis, Concordia University Department of Management, Montreal, Quebec, Canada.

Grant, A. M., \& Shin, J. (2011). Work motivation: Directing, energizing, and maintaining effort (and research). Forthcoming in R. M. Ryan (Ed.), Oxford handbook of motivation. Oxford University Press.

Harmer, J. (2001). The Practice of English Language Teaching. Essex: Longman Press.

Johnson, S. M. (1986). Incentives for Teachers: What Motivates, What Matter. Educational Administration Quarterly, 22/3, 54-79.

Joo, B. K., \& Lim, T. (2009). The effects of organizational learning culture, perceived job complexity, and proactive personality on organizational commitment and intrinsic motivation. Journal of Leadership \& Organizational Studies, 16 (1), 48-60.

Kanfer, R. (1990). Motivation theory and industrial and organizational psychology. In M. D. Dunnette (Ed.), Handbook of industrial and organizational psychology (Vol. 1, 2nd ed.,pp. 75-130). Palo Alto, CA: Consulting Psychologists Press.

Leonard, N. H., Beauvais, L. L., \& Scholl, R. W. (1999). Work motivation: The incorporation of selfconcept-based processes. Human Relations, 52 (8), 969-998.

Lin, H. F. (2007). Effects of extrinsic and intrinsic motivation on employee knowledge sharing intentions. Journal of Information Science, 33 (2), 135-149.

Littlejohn, A. (2008). The tip of the iceberg: Factors affecting learner motivation. Regional Language Centre Journal, 39 (2), 214-225.

Millette, V., \& Gagne, M. (2008). Designing volunteers' tasks to maximize motivation, satisfaction and performance: the impact of job characteristics on volunteer engagement. Motivation and Emotion, $32(1), 11-22$.

Oades, C. D. (1983). Relationship of teacher motivation and job satisfaction. Yayımlanmamış Doktora Tezi, University of Manitoba, Canada.

Osterloh, M., Frey, B. S., \& Frost, J. (2001). Managing motivation, organization and governance. Journal of Management and Governance, 5 (3-4), 231-239.

Örücü, E., \& Kambur, A. (2008). Örgütsel-yönetsel motivasyon faktörlerinin çalışanların performans ve verimliliğine etkilerini incelemeye yönelik ampirik bir çalışma: Hizmet ve endüstri işletmesi örneği. Yönetim ve Ekonomi, 15 (1), 85-97.

Öztürk, H. (2002). Hemşirelerin motivasyon düzeyleri ve performans düzeyleri. Yayımlanmamış Doktora Tezi, İstanbul Üniversitesi Sağlık Bilimleri Enstitüsü, İstanbul.

Öztürk, Z., \& Dündar, H. (2003). Örgütsel motivasyon ve kamu çalışanlarını motive eden faktörler. Cumhuriyet Üniversitesi İktisadi ve İdari Bilimler Dergisi, 4 (2), 57-67.

Pinder, C. C. (1998). Work Motivation in Organizational Behavior. Upper Saddle River, NJ: Prentice Hall.

Pennington, P. W. (1997). Principal leadership and teacher motivation in secondary schools. Yayımlanmamış Doktora Tezi, Tennessee State University Graduate School, Tennessee.

Recepoğlu, E., Kılınç, A. Ç., \& Çepni, O. (2011). The relationship between school principals' humor styles and motivation level of teachers. Educational Research and Review, 6 (17), 928-934.

Recepoğlu, E. (2013). A study on teachers' job motivation in the high schools of Ministry of National Education in Turkey (Karabük and Sinop Sample). Middle East Journal of Scientific Research, 13 (4), 532-537.

Ryan, R. M., \& Edward L. D. (2000). Intrinsic and Extrinsic Motivations: Classic Definitions and New Directions. Contemporary Educational Psychology, 25, 54-67.

Smith, T. M. (1999). A study of the relationship between principal's leadership style and teacher motivation: The teachers' perspective. Yayımlanmamış Doktora Tezi, Georgia State University College of Education, Georgia.

Steers, R. M., \& Lyman W. P. (1991). Motivation and work behavior. New York: McGraw-Hill.Inc. Lincoln. 
PROBLEMS

OF EDUCATION

IN THE $21^{\text {st }}$ CENTURY

Volume 51, 2013

112 Tanrıverdi, S. (2007). Katılımcı okul kültürünün yabancı dil öğretmenlerinin iş motivasyonuyla ilişkisine yönelik örnek bir çalışma. Yayımlanmamış Yüksek Lisans Tezi, Yeditepe Üniversitesi Sosyal Bilimler Enstitüsü, İstanbul.

Tiryaki, A. (2008). İşletmelerde modern liderlik yaklaşımları ve çalışan motivasyonu ilişkisine yönelik bir uygulama. Yayımlanmamış Yüksek Lisans Tezi, Yıldız Teknik Üniversitesi Sosyal Bilimler Enstitüsü, İstanbul.

Williams, M., \& Robert L. B. (1997). Psychology for language teachers: A social constructivist approach. Cambridge: Cambridge University Press.

Yılmaz, F. (2009). Eğitim örgütlerinde örgüt kültürünün ögretmenlerin iş motivasyonu üzerindeki etkisi. Yayımlanmamış Yüksek Lisans Tezi. Selçuk Üniversitesi, Sosyal Bilimler Enstitüsü, Konya.

Advised by Judita Stankutè, SMC "Scientia Educologica”, Lithuania

Received: January 08, 2012

Accepted: March 11, 2013

Ergün Recepoğlu Assistant Professor, Dr., Kastamonu University, Department of Educational Sciences, Kastamonu, Turkey.

E-mail: erecepoglu@kastamonu.edu.tr 